Force and Freedom 



\title{
Force and Freedom
}

\author{
Kant's Legal and Political Philosophy
}

\author{
Arthur Ripstein
}

Harvard University Press

Cambridge, Massachusetts · London, England 
Copyright (C 2009 by the President and Fellows of Harvard College All rights reserved

Printed in the United States of America

\section{Library of Congress Cataloging-in-Publication Data}

Ripstein, Arthur.

Force and freedom : Kant's legal and political philosophy / Arthur Ripstein.

p. $\mathrm{cm}$.

Includes bibliographical references and index.

ISBN 978-o-674-03506-5 (alk. paper)

1. Kant, Immanuel, 1724-1804-Political and social views. 2. Law-Philosophy. I. Title.

JC181.K4 8572009

$320.092-\mathrm{dc22} \quad 2009000225$ 
To Noah, Aviva, Karen

$\sim$

Fellow Kantians 
